ORIGINAL ARTICLES

\title{
Chemokine Receptor 7 Implications of Spleen Dendritic Cells in Multiple-organ Dysfunction Syndrome in Mice
}

G Hou*, J Lu, H Wang, Q Liu*, G Tian, Y Yang

\begin{abstract}
Objective: This study aims to explore the chemokine receptor 7 (CCR7) expression of spleen dendritic cells (DCs) and their role in the changes of migration and activity of spleen DCs in multiple-organ dysfunction syndrome (MODS).

Methods: The MODS model of mice was reproduced. The mice were randomly assigned to the following groups: normal, three-hour to six-hour, 24-hour to 48-hour, and 10-day to 12-day postzymosan injection. CD11c and CD205 were analysed by immunohistochemistry; the expressions of CD86 and CCR7 of DCs were studied using flow cytometry analyses.

Results: In normal mice, many DCs were found at the margin between the red and white pulp. In the three-hour to six-hour and 24- to 48-hour group, DC effectively upregulated CD86 and CCR7, and they were distributed in T-cell areas. In the 10-day to 12-day group, DCs were distributed at the margin by the immature form.

Conclusion: The CCR7 expression level of DCs had close correlations with the migration of DCs. Chemokine receptor 7 can be used to evaluate the migration and functional activity of DCs in MODS.
\end{abstract}

Keywords: Chemokine receptor 7 (CCR7), dendritic cell, multiple organ dysfunction syndrome (MODS), spleen

\section{Implicaciones del Receptor de la Quimiocina de Tipo 7 de las Células Dendríticas del Bazo en el Síndrome de Disfunción Orgánica Múltiple en Ratones

\author{
G Hou*, J Lu, H Wang, Q Liu*, G Tian, Y Yang
}

\begin{abstract}
RESUMEN
Objetivo: Este estudio persigue explorar la expresión del receptor de la quimiocina 7 (CCR7) de células dendríticas del bazo (CD), y su papel en los cambios de la migración y la actividad del las células DC del bazo en el síndrome de disfunción orgánica múltiple (SDOM).

Métodos: Se reprodujo el modelo SDOM de los ratones. Los ratones fueron asignados aleatoriamente a los siguientes grupos de inyección de post-zymosan: hora normal, tres a seis horas, 24 horas a 48 horas, y de 10 a 12 días. CD11c y CD205 fueron analizados mediante inmunohistoquímica. Las expresiones de CD86 y CCR7 de CD se estudiaron mediante análisis de citometría de flujo.

Resultados: En los ratones normales, muchas células CD fueron encontradas en el margen entre la pulpa roja y la blanca. En el grupo de tres a seis horas y el grupo de 24 a 48 horas, CD86 y CCR7 fueron efectivamente sobre-regulados en $C D$, y distribuidos en las áreas de células $T$. En el grupo de 10 a 12 dias, las CDs fueron distribuidas en el margen por la forma inmadura.
\end{abstract}

From: Department of Pathology, First Affiliated Hospital of General Hospital of PLA, Beijing 100037, China.

*contributed equally to the manuscript
Correspondence: Dr J Lu, Department of Pathology, First Affiliated Hospital of General Hospital of PLA, Beijing 100037, China. E-mail: jiangyanglucn@yeah.net 
Conclusión: El nivel de expresión CCR7 de las CDs tuvo estrecha correlación con la migración de las CDs. El receptor de la quimiocina de tipo 7 puede utilizarse para evaluar la migración y la actividad funcional de las CDs en SDOM.

Palabras claves: Quimiocina de tipo 7 (CCR7), células dendríticas, síndrome de disfunción orgánica múltiple (SDOM), bazo

West Indian Med J 2013; 62 (9): 788

\section{INTRODUCTION}

Multiple-organ dysfunction syndrome (MODS) is a multiplesystem or multiple-organ dysfunction caused by systemic inflammatory response syndrome due to attacks such as trauma, shock, infection and inflammation. Its incidence rate and mortality rate are extremely high. In addition, MODS is the primary cause of death of patients in the surgical intensive care unit $(1,2)$. In recent years, relevant studies on the immunologic derangement mechanism of MODS suggest that the dendritic cell (DC) participates in the occurrence and development process of immune imbalance and immunosuppression of MODS and is important in the immunologic derangement of MODS (3-5). Immunohistochemical labelling studies prove that normal splenic DC distributes mainly in the marginal zone, which is possibly associated with the function of the DC-capturing antigen. The DC antigen presenting function requires DC contact with the T-cell, and thus DC migrates from the marginal zone to the T-cell zone. Dendritic cell migration is completed via interactions of multiple chemokines. Therefore, chemokine is closely related to DC function. This study uses the MODS mouse model to further investigate the changes and significances of the chemokine receptor 7 (CCR7) expression level of splenic DC and its immunologic function in the occurrence process of MODS to provide a new immune pathological basis for the pathogenesis, prevention and treatment of MODS.

\section{SUBJECTS AND METHODS}

A total of 40 male $\mathrm{C} 57 \mathrm{BL} / 6$ mice with body weights ranging from $20 \mathrm{~g}$ to $25 \mathrm{~g}$ and ages ranging from six weeks to eight weeks were purchased from the Experimental Animal Centre of Military Medical Science Academy. They were randomly assigned to the control group (10 mice) and the test group (30 mice). This study was conducted in strict accordance with the Guide for the Care and Use of Laboratory Animals of the National Institutes of Health. Animal use protocol was reviewed and approved by the Institutional Animal Care and Use Committee of the First Affiliated Hospital of the General Hospital of PLA. In the normal control group, 10 mice were fed conventionally. The test group was further divided into the three-hour to six-hour, 24-hour to 48-hour, and 10-day to 12-day subgroups after zymosan-caused trauma (10 mice in each subgroup). For each group of mice, sampling was conducted by killing live mice.

Multiple-organ dysfunction syndrome model preparation was conducted following previous studies $(6,7)$ as follows: $1 \mathrm{~g}$ zymosan powder and $40 \mathrm{~mL}$ medical liquid paraffin wax were mixed well for 1.5 hours by highfrequency magnetic stirring and combined with $25 \mathrm{~g} / \mathrm{L}$ zymosan suspension. The zymosan suspension was sterilized in $100{ }^{\circ} \mathrm{C}$ water bath for 80 minutes and cooled to room temperature. Before use, it was heated to $40{ }^{\circ} \mathrm{C}$. For mice in the test group, zymosan suspension ( $1 \mathrm{mg} / \mathrm{g}$ body weight) was administered by intraperitoneal aseptic injection. At the corresponding time phase points, sampling was conducted by killing live mice. For mice in the normal control group, sampling was randomly conducted by killing live mice.

Various groups of spleen tissues were embedded with OCT and sectioned with the cryostat. (i) The CD11c marker, hamster anti-mouse CD11c antibody (1:25) was added and incubated at room temperature for one hour. Subsequently, the second antibody-biotinylated anti-hamster $\operatorname{IgG}(1: 50)$ was added and incubated at room temperature for 30 minutes. The horseradish enzyme labelled streptavidin avidin (1:50) was added and incubated at room temperature for 30 minutes. Then, DAB developing and haematoxylin re-staining were done. (ii) The CD205 marker, rat anti-mouse CD205 antibody $(1: 25)$ was added and left overnight. Subsequently, the enzyme labelled second antibody (1:100) was added and incubated at room temperature for 60 minutes. Next, DAB developing and haematoxylin re-staining were conducted. In addition, the first antibody was replaced with antibody dilution in the negative control group.

Various groups of splenic monoplast suspensions (cell concentration: $\left.1.5 \times 10^{7} / \mathrm{mL}\right)$ were prepared. Each group of cell suspension (100:1) was placed into the flow tube, and fluorescent-labelled antibody was added until its final concentration reached $1 \mathrm{~g} / \mathrm{L}$ and mixed. Subsequently, the mixture was placed in a refrigerator at $4{ }^{\circ} \mathrm{C}$ for 30 minutes and then washed with PBS three times. Lastly, the flow cytometer was used to detect the expression rates of positive cells by labelled CD11c/CD86 and CD11c/CCR7.

SPSS 13.0 statistical analysis software was used. Measurement data were expressed as mean \pm standard deviation $(\overline{\times} \pm \mathrm{s})$, and $t$-test was used for comparison between the two groups. If $p<0.05$, then a significant difference could be observed.

\section{RESULTS}

\section{Immunohistochemistry}

In the normal control group, more brown yellow CD11c positive cells in the margin of the white pulp of mouse spleen 
were observed, whereas only a few sporadic positive cells were visible in the T-cell zone (Fig. 1A). In the three-hour to six-hour group, CD11c positive cells migrated from the marginal zone to the T-cell zone and increased, whereas the positive cells in the marginal zone decreased (Fig. 1B). In the 24-hour to 48-hour group, the CD11c positive cells decreased but were still distributed mainly in the T-cell zone of the white pulp (Fig. 1C). In the 10-day to 12-day group, CD11c positive cells were distributed mainly in the marginal zone, and only a few positive cells were visible in the T-cell zone (Fig. 1D).

\section{Flow cytometry}

In the three-hour to six-hour group, the percentage of $\mathrm{CD}^{2} 6^{+} / \mathrm{CD} 11 \mathrm{c}^{+} \mathrm{DC}$ in splenic mononuclear cell significantly increased, and an extremely significant difference was observed between the three- to six-hour group and the control group $(p<0.01)$. The percentage of $\mathrm{CD} 86^{+} / \mathrm{CD} 11 \mathrm{c}^{+} \mathrm{DC}$ of the 24-hour to 48-hour group was slightly reduced, but a significant difference $(p<0.05)$ was observed between the 24-hour to 48-hour group and the control group. The percentage of $\mathrm{CD} 6^{+} / \mathrm{CD} 11 \mathrm{c}^{+} \mathrm{DC}$ of the five-day to seven-

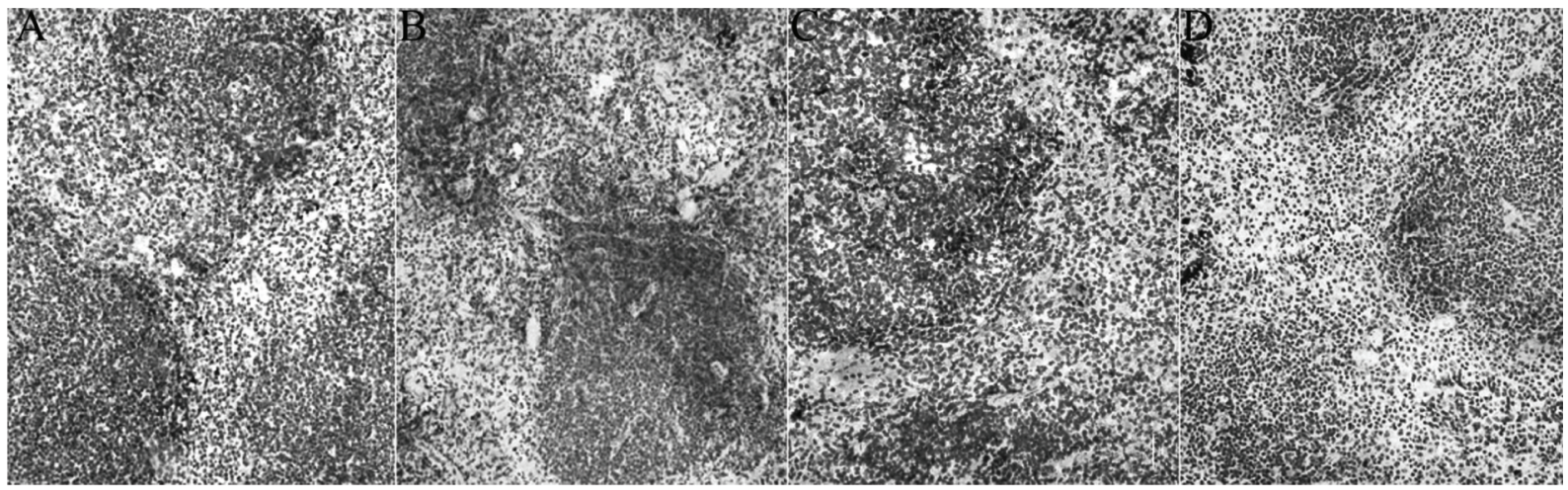

Fig. 1: Immunochemical staining for splenic dendritic cells (CD11c; × 100). A) control group; B) 3-6-hour group; C) 24-48-hour group; D) 10-12-day group.

In the normal control group, only a few CD205 positive cells (Fig. 2A) were visible in the marginal zone of the white pulp in mouse spleen. In the three- to six-hour group, CD205 positive cells distributed in the T-cell zone of the white pulp were visible (Fig. 2B). In the 24-hour to 48-hour group, splenic CD205 positive cells were reduced but still distributed mainly in the T-cell zone (Fig. 2C). In the 10-day to 12-day group, splenic CD205 positive cells were evidently reduced and distributed mainly in the marginal zone (Fig. 2D). day group was close to that of the control group, while that of the 10-day to 12-day group was significantly reduced. Between the 10-day to 12-day group and the control group, a significant difference $(p<0.01)$ was observed (Fig. 3).

The percentage of $\mathrm{CCR}^{+} / \mathrm{CD} 11 \mathrm{c}^{+} \mathrm{DC}$ in splenic mononuclear cells of the three-hour to six-hour group began to increase, and a significant difference was observed between this group and the normal control group $(p<0.05)$. That of the 24-hour to 48-hour group reached the peak, and a significant difference was observed between this group and

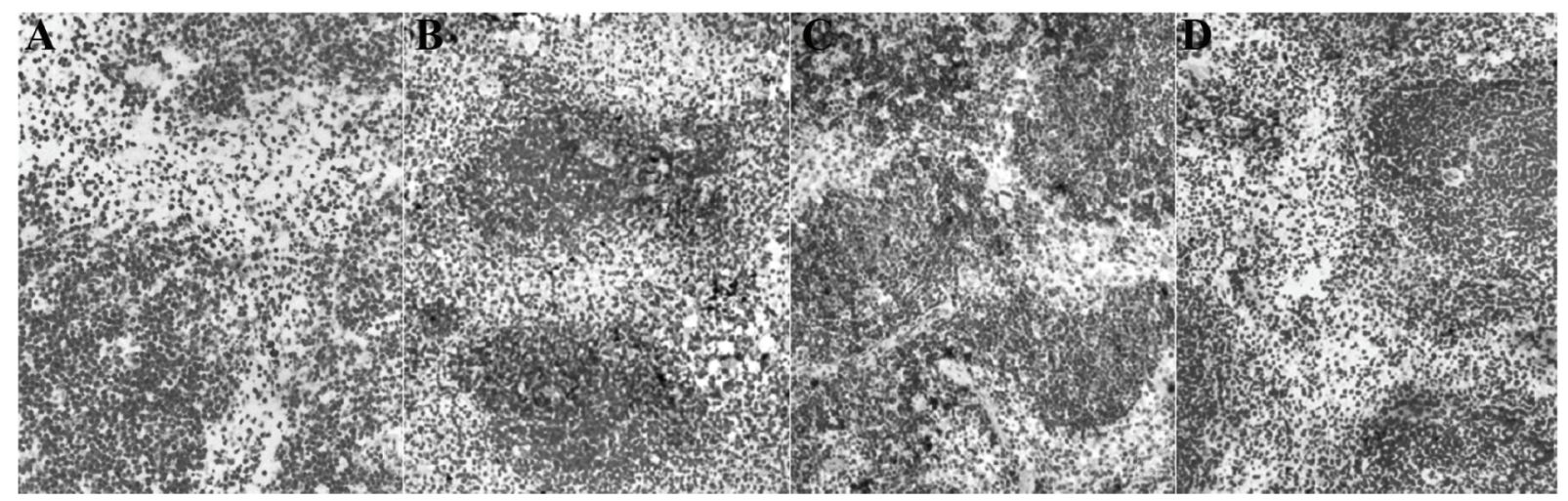

Fig. 2: Immunochemical staining for splenic dendritic cells (CD205; Envision $\times 200$ ). A) control group; B) 3-6-hour group; C) 24-48-hour group; D) 10-12-day group. 
A

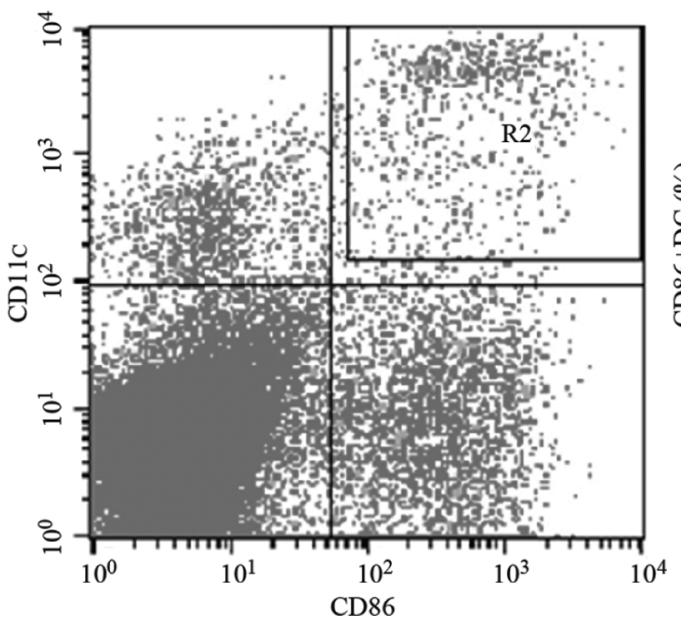

B

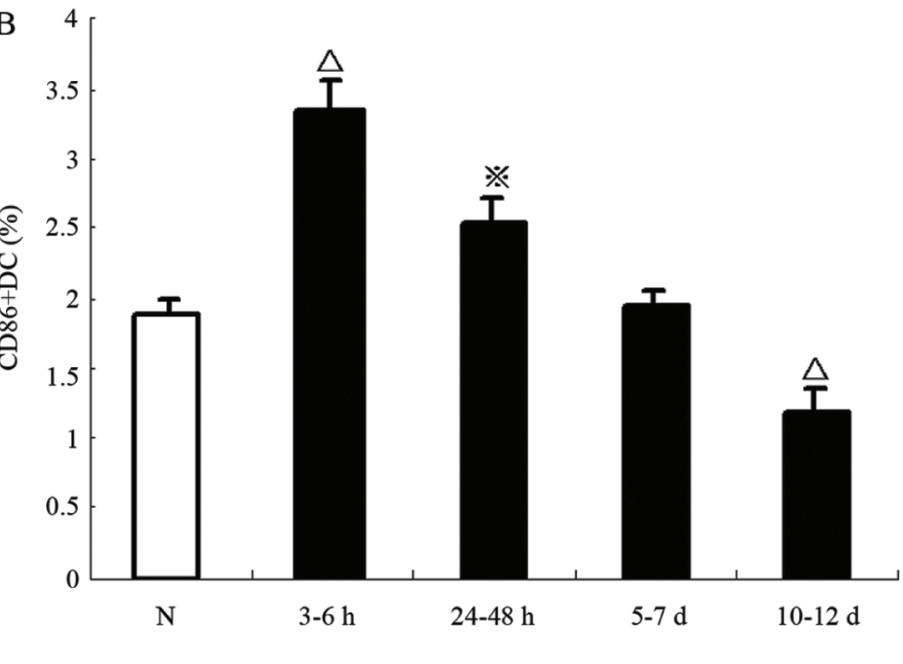

Fig. 3: Changes of the quantity of splenic $\mathrm{CD} 86^{+} / \mathrm{CD} 11 \mathrm{c}^{+}$dendritic cells in multiple-organ dysfunction syndrome mice. Note: versus the control group, ${ }^{*} p<0.05, \Delta p<0.01$

the control group $(p<0.01)$. That of the five-day to sevenday group decreased to the same level as the normal control group. That of the 10-day to 12-day group significantly decreased, being slightly lower than that of the normal control group, but no significant difference was observed between this group and the control group (Fig. 4). is a powerful special antigen-presenting cell, and active mature DCs can migrate toward the T-cell region, can induce the T-cell to generate specific immune responses and can be important in the regulation of immunologic function of the Tcell $(11,12)$. Chemokine receptors are critical in the process of mediating DC migration. Chemokine receptor 7 is one
A

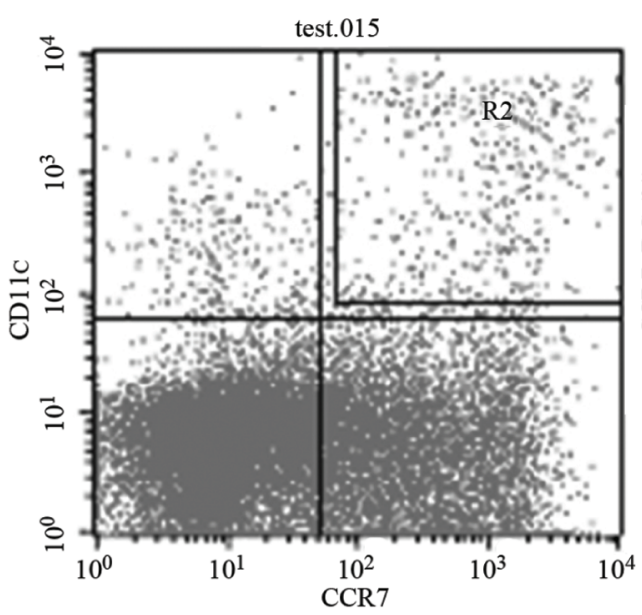

B 6

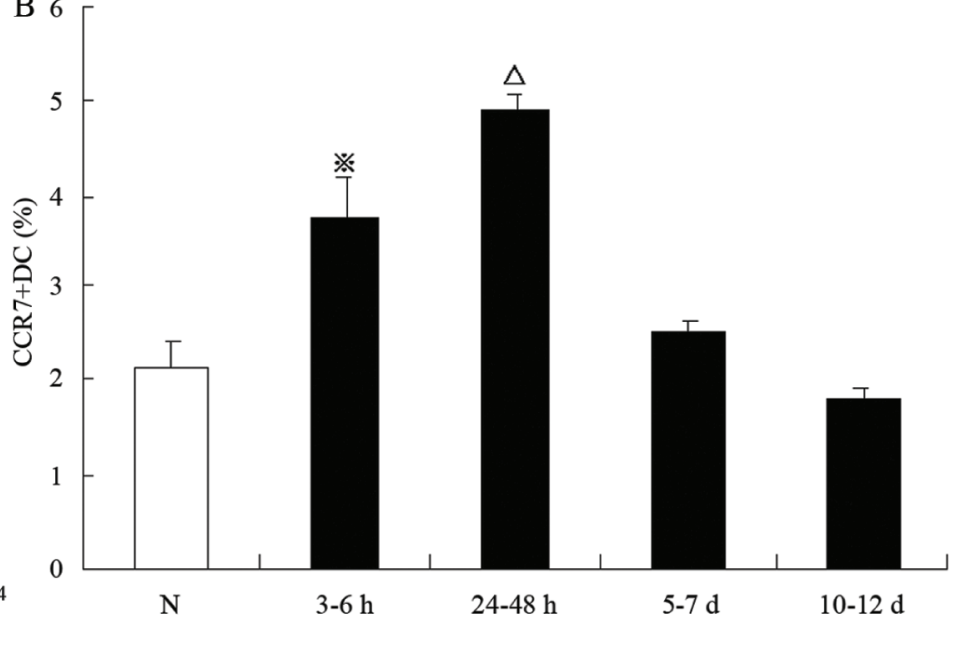

Fig. 4: Changes of the quantity of splenic $\mathrm{CCR} 7^{+} / \mathrm{CD} 11 \mathrm{c}^{+}$dendritic cells in multiple-organ dysfunction syndrome mice. Note: versus the control group, ${ }^{*} p<0.05,{ }^{\Delta} p<0.01$.

\section{DISCUSSION}

Zymosan-caused MODS model of mice can better simulate the "dual phase attack" disease of clinical MODS (5-7). Previous studies suggested that organs with pathological changes subject to the attacks in the early stage of MODS were immune organs that manifested extremely high immune or immunologic derangement and manifested immunosuppression in the advanced stage $(5,8-10)$. Dendritic cell important member of the $\mathrm{C}$ family of chemokine receptors, and it is essential in inducing DC migration (13-17). Previous studies on DC in pulmonary parenchyma of MODS mice showed that CCR7 expression level was closely related to the migration activity of DC in pulmonary parenchyma and immune response level of the body (18). Thus, more studies on the correlations of CCR7 expression change of splenic DC in the disease course of MODS with DC immuno- 
phenotype and migration ability will further clarify the close relationship of immunologic dysfunction of splenic DC with immunologic derangement of MODS and explore the immunopathological mechanism of MODS.

CD11c and CD205 are used as markers of splenic DC. At present, CD11c is a widely used characteristic marker of mature and immature DCs, whereas only a few NK cells also express CD11c (19). CD205 is one kind of agglutininmediating antigen presentation function, and it is expressed only on the surface of mature active DC (20). Immunohistochemical labelling results of CD11c and CD205 show that DC cells are in an immature status in the normal mouse spleen (express CD11c rather than CD205) distributing mainly near the splenic marginal zone. In addition, these DC cells express CCR7 extremely slowly. In the early stage of MODS (before 48 hours), CCR7 expression level of DC significantly increases. At this time, immunohistochemical labelled positive cells of CD11c and CD205 migrate, distributing in mature status mainly in the T-cell region of the splenic white pulp. In the advanced stage of MODS (10 days to 12 days), CCR7 expression level of DC significantly decreases and is lower than the normal expression level of mice. Immunohistochemical labelling results of CD11c and CD205 of DC also show that immature DC distributes near the margin. The above results suggest that the DC migration process in the spleen is closely related to its CCR7 expression level. Chemokine receptor 7 expression level of DC significantly increases, accompanied by DC migrating from the marginal zone to the T-cell zone of white pulp in MODS. In the advanced stage of MODS, CCR7 expression level of DC is extremely low. Simultaneously, DC is detained near the marginal zone. In addition, the DC migration process in the spleen is closely related to its CCR7 expression level. Dendritic cells migrate from the splenic margin to the T-cell zone, while CCR7 expressions are increasing. Therefore, CCR7 expression level is one indicator of the migration ability of splenic DC.

CD86 is an important surface molecule of DC presenting antigen and induce immune responses with a high level of expression on the surface of the mature active DC (6). The flow cytometry assay result of CD86 expression of DC shows that the CD86 expression level constantly and rapidly increases in the early stage of MODS, which is consistent with the change of CCR7 expression. Chemokine receptor 7 expression level of DC given excessive zymosan, increases in the early stage of MODS, and DC activity is enhanced. Therefore, the body experiences a strong inflammatory reaction and the "first attack" of the model is formed. In the advanced stage of MODS (10 days to 12 days), CD86 and CCR7 expression levels of DC are normal. At this time, $\mathrm{DC}$ is in an immature status, and the activity is very low, which causes immunosuppression and MODS.

Chemokine receptor 7 expression level of DC reflects the migration activity and maturation status of splenic DC in the disease course of MODS, and CCR7 expression abnor- mality is one important link to the immunologic derangement process of MODS. The pathogenesis of MODS should be further clarified, and effective prevention and control measures should be provided to inhibit the occurrence of immune hyperfunction or immunosuppression by changing or regulating the CCR7 expression level of splenic DC.

\section{ACKNOWLEDGEMENTS}

This project was funded by "Eleventh Five" Medical Research Project of PLA (06MB307).

\section{REFERENCES}

1. Seely JE, Christou NV. Multiple organ dysfunction syndrome: exploring the paradigm of complex nonlinear systems. Crit Care Med 2000; 28: 2193-2000.

2. Sheng ZY, Hu S. Multiple organ dysfunction syndrome. $2^{\text {nd }}$ ed. Science Publishing House; 2003: 1-63.

3. Cohen J. The immunopathogenesis of sepsis. Nature 2002; 420: 885-91.

4. Efron P, Moldawer LL. Sepsis and the dendritic cell. Shock 2003; 20: 386-401.

5. Lu JY, Wang XH, Liu Q, Yang Y, Li L. Pathologic alteration of spleen and its dendritic cells in patients with multiple organ dysfunction syndrome: an observation of 52 autopsied cases. Chin J Diagnostic Pathol 2007; 14: 172-5.

6. Jansen MJ, Jendriks T, Verhofstad AA, Lange W, Geeraedts LM Jr, Goris RJ. Gradual development of organ damage in the murine zymozan-induced multiple organ dysfunction syndrome. Shock 1997; 8: $261-7$.

7. Sun Y, Lu JY, Wang XH, Hu S, Yang Y, Tong X. Replication of animal model and pathological study of delayed multiple organ dysfunction syndrome in mice. Chin Crit Care Med 2003; 15: 15-8.

8. Lu JY, Li ZH, Wang XH, Yang Y, Li L. Changes in spleen dendritic cells in multiple organ dysfunction syndrome in mice. Chin Crit Care Med 2006; 18: 24-6.

9. Tian G, Lu JY, Wang HW, Liu X, Yang Y. Protective effect of Flt3 ligand on organ function and structure in mice with multiple organ dysfunction syndrome. Chin Crit Care Med 2008; 20: 45-8.

10. Flohé SB, Agrawal H, Schmitz D, Gertz M, Flohé S, Schade FU. Dendritic cells during polymicrobial sepsis rapidly mature but fail to initiate a protective Th1-type immune response. J Leukoc Biol 2006; 79: 473-81

11. Cervantes-Barragan L, Lewis KL, Firner S, Thiel V, Hugues S, Reith W et al. Plasmacytoid dendritic cells control T-cell response to chronic viral infection. Proc Natl Acad Sci USA 2012; 109: 3012-7.

12. Ostrand-Rosenberg S, Sinha P, Beury DW, Clements VK. Cross-talk between myeloid-derived suppressor cells (MDSC), macrophages, and dendritic cells enhances tumor-induced immune suppression. Semin Cancer Biol 2012; 22: 275-81.

13. Sánchez-Sánchez N, Riol-Blanco L, de la Rosa G, Puig-Kröger A, García-Bordas J, Martín D et al. Chemokine receptor CCR7 induces intracellular signaling that inhibits apoptosis of mature dendritic cell. Blood 2004; 104: 619-25.

14. Hirao M, Onai N, Hiroishi K, Watkins SC, Matsushima K, Robbins PD et al. CC Chemokine receptor-7 on dendritic cells is induced after interaction with apoptotic tumor cell: critical role in migration from the tumor site to draining lymph nodes. Cancer Res 2000; 60: 2209-17.

15. Yoneyama H, Matsuno K, Zhang Y, Murai M, Itakura M, Ishikawa S et al. Regulation by chemokines of circulating dendritic cell precursors, and the formation of portal tract-associated lymphoid tissue, in a granulomatous liver disease. J Exp Med 2001; 193: 35-49.

16. Umemoto E, Otani K, Ikeno T, Verjan Garcia N, Hayasaka H, Bai Z et al. Constitutive plasmacytoid dendritic cell migration to the splenic white pulp is cooperatively regulated by CCR7- and CXCR4-mediated signaling. J Immunol 2012; 189: 191-9. 
17. Seth S, Oberdörfer L, Hyde R, Hoff K, Thies V, Worbs T et al. CCR7 essentially contributes to the homing of plasmacytoid dendritic cells to lymph nodes under steady-state as well as inflammatory conditions. J Immunol 2011; 186: 3364-72.

18. Wang HW, Lu JY, Wang XH, Tian G, Yang Y, Li L. Observation of morphology and distribution of interstitial dendritic cells in mouse lung. Chin J Pathol 2007; 5: 307-12.
19. Maraskovsky E, Brasel K, Teepe M, Roux ER, Lyman SD, Shortman K et al. Dramatic increase in the numbers of functionally mature dendritic cells in Flt3 ligand-treated mice: multiple dendritic cell subpopulations identified. J Exp Med 1996; 184: 1953-62.

20. Gliddon DR, Hope JC, Brooke GP, Howard CJ. DEC-205 expression on migrating dendritic cells in afferent lymph. Immunology 2004; 111: $262-72$. 